\title{
Effect of blade pitch angle on the aerodynamic characteristics of a twisted blade horizontal axis wind turbine based on numerical simulations
}

\author{
Rajendra Roul, Awadhesh Kumar \\ Department of Civil Engineering, National Institute of Technology Rourkela, Rourkela, India
}

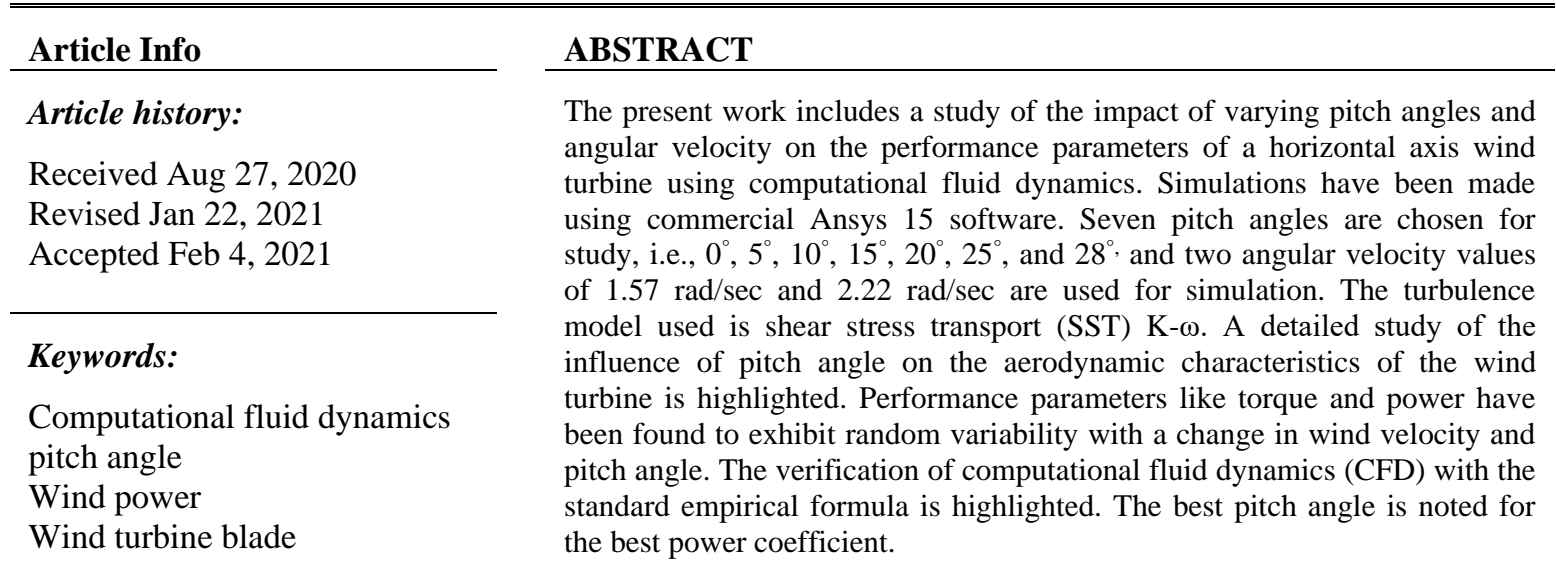

This is an open access article under the CC BY-SA license.

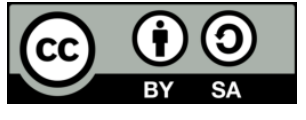

\section{Corresponding Author:}

Rajendra Roul

Department of Civil Engineering,

National Institute of Technology, Rourkela

Pin-769008, Odisha, India

Email: rajendraroulnit@gmail.com

\section{INTRODUCTION}

The use and supply of fossil fuels have been declining over the last ten years due to their adverse effects on the environment, which in turn raises the demand for renewable energy sources [1]. Support for the use of renewable energy sources has been enhanced, not by improving power efficiency, but by maintaining the climate target criteria [2] and thus increasing the dependency of the renewable energy source as a means of mitigating the traditional way of generating energy on the environment. Electricity is not only an essential factor for human society's growth and advancement but also plays a crucial role in economic and product production in the industrial sector [3]. Because of that, power should be available to any corner of the planet. One way of generating electricity is to use wind as a source of renewable energy and use it through a wind turbine that can convert the kinetic energy in the wind into meaningful electricity [4]. Another way is to use the photovoltaic cell, where the production of power is carried out by converting the solar radiation through the photoelectrical effect process. Despite the more outstanding performance and cost-effectiveness of photovoltaic panel technology, the use of wind power has increased in recent years. In 2017, for example, $34 \%$ of wind turbine growth was observed in Europe in comparison to 2016 [5]. Wind turbine technology has become a popular field of research because of increasing demand. The usage of wind turbines is not only fulfilling the need of the energy industry but also becomes an important area of researching the various academic field. Nowadays researchers are focusing on developing micro wind turbines installed in various 
applications like in bicycle as a portable charger [6], in-home, and building as a source of electricity [7]. Various control techniques have been conducted to increase power efficiency [8]-[17] and monitor aeroelasticity structural damage [18], [19]. Also, many research projects have focused on intensifying the use of wind turbines in a turbulence environment and because of this, computational techniques have been utilized in wind power production platform that involves significant research areas such as micro-locations, wind simulation, forecasting, and blade optimization [20]. Few researchers have used the Blade element method (BEM) code in wind turbine applications to operate to its maximum power coefficients [21]. They found an ideal rotational speed that provides optimal power for a specified streamlining speed. In addition to it, an updated BEM theory has also been used to simulate forces on large-scale wind turbines to simulate the dynamic model. It has been found that this dynamic model was most appropriate for engineering purposes [22]. Due to the rise in demand for BEM its application is increased from designing a horizontal axis wind turbine blade to developing a mathematical model [23]. However, the BEM method failed to simulate the whole flow field. Due to this drawback of the BEM method, several investigators have employed the computational fluid dynamics (CFD) technique in modeling the National Renewable Energy Laboratory (NREL) turbines by solving Navier stocks equations [24]-[26]. The wind turbine is composed of various parts like blades, tower, gearbox, generator, controller and many more things and every part have their importance but among all other parts, blade plays an important role in determining the efficiency of the wind turbine. So, for an efficient wind turbine, a study on the blade is necessary to get the optimum results, and for this, the idea of twist angle and pitch angle is necessary. Researchers used the un-twisted blade to get the best angle of attack by conducting several simulations for various wind speeds. The test parameters included fivepitch angles and four wind speeds. The results obtained from the CFD Analysis were compared with the experimental results from the NREL [27]. Moreover, few authors also have examined NREL Phase VI smallsized wind turbines for comprehending their aerodynamic behavior using the CFD technique. To execute the analysis, they considered five wind speeds and a constant pitch angle and for modeling turbulence, the Shear stress transport (SST) k-w model was considered. They found the stall at the blade root at $7 \mathrm{~m} / \mathrm{s}$ [28]. Some of the researchers also used code called CFD Ship-Iowa 4.5, which is dynamic and uses the property of incompressible to check the performance parameter of NREL phase VI. Using these code two objectives of the NREL phase VI wind turbine are completed. One is performing analysis by fixing pitch angle and varying wind speed and the second is performing analysis by fixing wind speed and varying pitch angle. In both the case, rotor rotational speed has been taken as $7.53 \mathrm{rad} / \mathrm{sec}$. Here detached eddy simulation has been used as a turbulence model. The experimental results validated various performance parameters, such as power, thrust, and pressure variations around the airfoil [29].

As proper monitoring of the blade pitch mechanism is required, there have also been a few suggestions for minimizing wear in the wind turbine pitch drive [30]. Also, several valued logics such as fuzzy logic is utilized and optimization processes such as genetic algorithms, meta-heurestic, cuckoo search algorithm and Particle Swarm Optimization (PSO) have been used to monitor the pitch angle by accommodating nonlinearity, which further leads to stability in the wind turbine system by reducing charging effects on a wind turbine blade [31]-[40]. Hence from the previous literature, it is clear that pitch angle plays a vital role in determining the wind turbine performance. So, the purpose of this research is to examine the influence of a pitch angle on the performance factor of the horizontal axis wind turbine blade by considering different pitch angles and rotational speed at different wind speeds. This research can give the researcher data to design and optimize the blade effectively by identifying the optimal pitch angle for the corresponding speed. For the numerical simulation of the wind turbine, aerodynamic analysis for different pitch angle and wind speed was carried out using the Ansys Fluent 15 CFD simulation [41].

The novelty of this paper is described as follows:

- In the previous literature, either lower-fidelity modeling or a few pitch angle values were investigated for its impact on HAWT efficiency. To better understand the effectiveness of pitch angle on turbine output it is necessary to consider more pitch angles, as a result, a complete understanding of turbine performance is lacking with the involvement of few pitch angles. The present research is complementary to the existing knowledge by using highly precise CFD measurements and the association of more pitch angles.

- The working conditions examined include seven-pitch angles, two different rotational speeds, and seventeen different wind speeds. In previous literature, this kind of working environment was not used to provide a more comprehensive view of how the aerodynamic efficiency varies at the next pitch angles.

This paper is organized as follows: Section 2 represents a methodology, which comprises threecomponent, i.e., wind turbine model, domain and meshing, and physics setup. Section 3 presents results and discussions followed by the conclusion in section 4 . 


\section{METHOD}

The method is divided into three parts, first is the selection of airfoil and blade design for the wind turbine. Second is the formation of computational domain and meshing, and the final is the selection of the algorithm for physics setup.

\subsection{Wind turbine model}

Figure 1(a) displays the wind turbine model considered in this article. The three-dimensional wind turbine blade is constructed with the geometrical parameters suggested in the report [42]. This blade includes 3 type of airfoils that are mounted from root to tip shown in Figure 1(b). The blade and rotor parameters are defined in Table 1. For an effective design of the wind turbine rotor, it is mandatory to know the structural and aerodynamic requirements. From an aerodynamic standpoint, a thin airfoil must be preferred to get a higher lift. From a structural point of view, dense airfoils must be chosen for high rigidity, and failures due to bending must be eliminated. In the design process, meeting these two requirements is of utmost importance. To satisfy both aerodynamic and structural demands, various airfoils must be mounted at a separate section of the blade. A thick airfoil is used on the root of this paper and a thin airfoil on the tip section is mounted. This article takes one meter additionally to show the blade attached to a hub and compensates for the blade root by 1 meter from the rotation axis. This paper does not involve the hub.

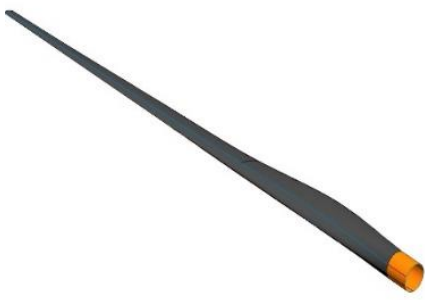

(a)

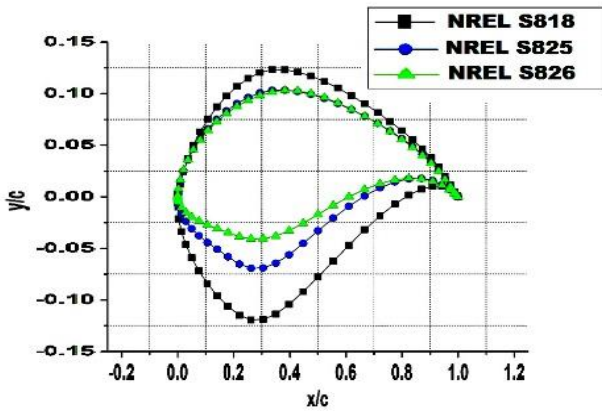

(b)

Figure 1. (a) 3D wind turbine blade, (b) NREL airfoils

Table 1. Important specifications of the wind turbine

\begin{tabular}{ccc}
\hline Important factors & value & Unit \\
\hline Power & 1.5 & MW \\
Number of blades NB & 3 & Not Applicable \\
Rotor Radius R & 43.25 & Metre \\
Rotational velocities & $1.57,2.22$ & rad/sec \\
Pitch angle & $0,5,10,15,20,25,28$ & Degree \\
Velocities & $8,9,10,11,12,13,14,15,16,17,18,19,20,21,22,23,24$ & $\mathrm{~m} / \mathrm{s}$ \\
\hline
\end{tabular}

\subsection{Domain and meshing}

The model will use a periodicity boundary condition. ANSYS builds equations that make the solution on the $0^{\circ}$ and $120^{\circ}$ planes equal. When the results are expanded, the $240^{\circ}$ plane will have the same values as the $0^{\circ}$ and $120^{\circ}$ planes. The values on the $60^{\circ}$ plane will be the same as the values on the $180^{\circ}$ plane after the results are expanded. The width between the domain inlet and outlet is $270 \mathrm{~m}$. The global origin is placed in the middle of the blade root when constructing the domain. The distance from the blade to the velocity inlet and the pressure outlet is shown in Figure 2. The upper portion of the computational domain is considered as top velocity and is given the same input as inlet velocity. The radius at inlet and outlet $\mathrm{s}$ taken as $120^{\circ}$ degree and $240^{\circ}$ degree. The computational domain and boundary conditions for the wind turbine model are depicted in Figure 2. This paper uses structured grids which are symbolized by tetrahedral elements in 3D. Thus, the mesh of the fluid domain reflects tetrahedral form, as seen in Figure 3. Also, the prismatic inflation layer is added for outward flow to trap the boundary layer on an entity. The sphere of influence was used with a radius of $30 \mathrm{~m}$ and an element size of $2 \mathrm{~m}$ to establish further precision along the circumference. 


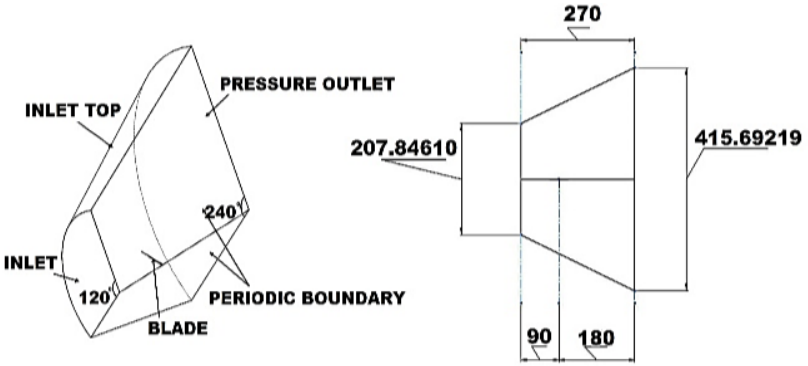

Figure 2. Computational domain with boundary conditions

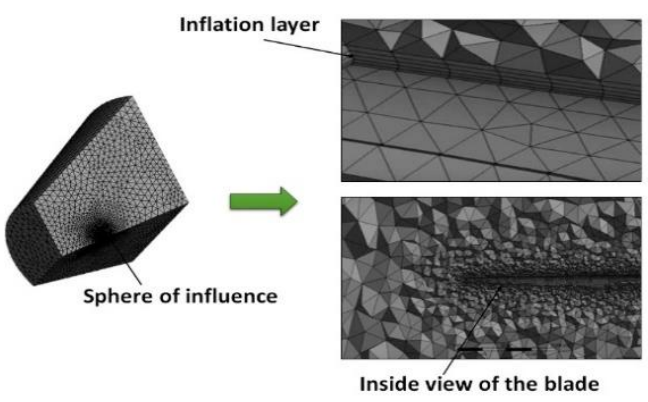

Figure 3. Mesh of the computational domain

\subsection{Physics setup}

In this paper, a pressure-based steady-state CFD simulation has been performed. The turbulence model used for this study is k-omega SST. In solution methods, pressure-velocity coupling was implemented, and algorithms used to calculate gradients and pressure are the least-squares cell-based algorithm and the standard algorithm. Moreover, for evaluating the momentum equation second-order upwind algorithm and for turbulent kinetic energy, and specific dissipation rate first-order upwind algorithm were taken. The residuals are monitored to 1500 iteration to reach the convergence.

\section{RESULTS AND DISCUSSIONS}

\subsection{Estimation of torque}

As the blade is generally designed for many pitches and wind velocities, the optimum pitch angle will be activated to an automated control mechanism for a particular wind velocity to generate maximum torque. Torque generation by the blade not only depends on the velocity of incoming airflow, but it also depends on the rate of change of momentum, as the frontal area changes for different pitches, which in result gives the modified rate of flow and leads to torque generation. Here Figure 4 (a) and Figure 4(b) shows that when the pitch angle $25^{\circ}$ and $28^{\circ}$ are considered, and the flow velocity varies from $8 \mathrm{~m} / \mathrm{s}$ to $24 \mathrm{~m} / \mathrm{s}$, torque decreases monotonically. In contrast to other pitch angles initially it falls and then increases. The maximum torque obtained is corresponding to a $28^{\circ}$ pitch angle for a wind velocity of $8 \mathrm{~m} / \mathrm{s}$. From Figure s $4(\mathrm{a})$ and Figure 4(b), it has been observed that as the rotational velocity increases, torque generation by a wind turbine rises corresponding to all pitches and wind velocities. It is to be noted when $\omega=1.57 \mathrm{rad} / \mathrm{sec}$ and pitch angle $0^{\circ}$ is considered for the analysis, the graph of torque shows an increasing trend. But, when $\omega=2.22 \mathrm{rad} / \mathrm{sec}$ and a pitch angle $0^{\circ}$ is considered there is a fall in torque value when velocity changes from $8 \mathrm{~m} / \mathrm{s}$ to $10 \mathrm{~m} / \mathrm{s}$, and after that, it rises with an increase in wind speed.

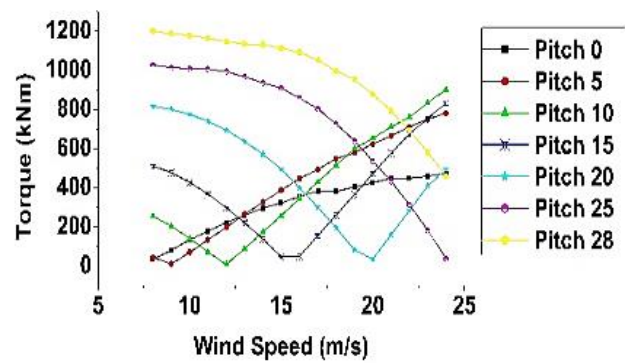

(a)

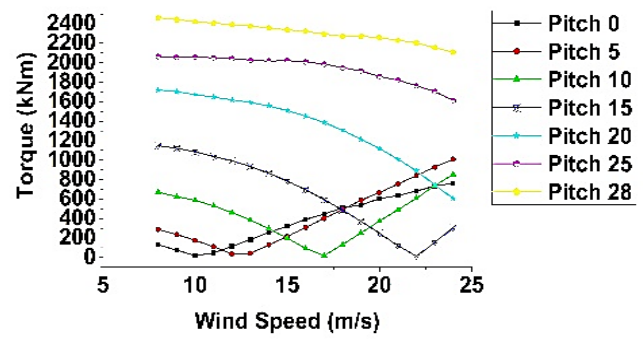

(b)

Figure 4 Torque variation curve at different pitch angle for (a) $\omega=1.57 \mathrm{rad} / \mathrm{sec}$, (b) $\omega=2.22 \mathrm{rad} / \mathrm{sec}$

\subsection{Estimation of power}

The numerical power can be easily calculated using the following equation after the torque value is received from the CFD simulation. 


$$
P=T \times \omega
$$

where, $P=$ power $(M W)$

$T=\operatorname{torque}(N-m)$

$\omega=$ angular velocity $(\mathrm{rad} / \mathrm{sec})$

The variation of the power curve shown in Figure 5(a) and Figure 5(b) is the same as Figure 4(a) and Figure 4(b). Here in Figure 5(a), pitch angle $25^{\circ}$ and $28^{\circ}$ shows the decreasing trend, and it happens in such a way that from velocity $8 \mathrm{~m} / \mathrm{s}$ to $16 \mathrm{~m} / \mathrm{s}$, the curve shows flat fall, but after $16 \mathrm{~m} / \mathrm{s}$, it decreased sharply. But in Figure 5(b), when the blade is given pitch angle $25^{\circ}$ and $28^{\circ}$, the curve shows flat decrement consistently irrespective of wind speed. In both the above cases, despite the decreasing trend, it has been observed that power is coming to be more than expected for $25^{\circ}$ and $28^{\circ}$ pitch angles, which are more than the rated power output value shown in table 1, it is showing because losses like mechanical losses, rotor control system losses, pitch control mechanism losses, gear \& shaft losses, etc. are not considered while performing the simulations. The variation of pitch angle $25^{\circ}$ and pitch angle $28^{\circ}$ is shown in Figure 5 (a) and the variation of pitch angle $20^{\circ}$ shown in Figure 5(b) resembles each other. The reason behind the variation in the power curve is due to stall phenomena.

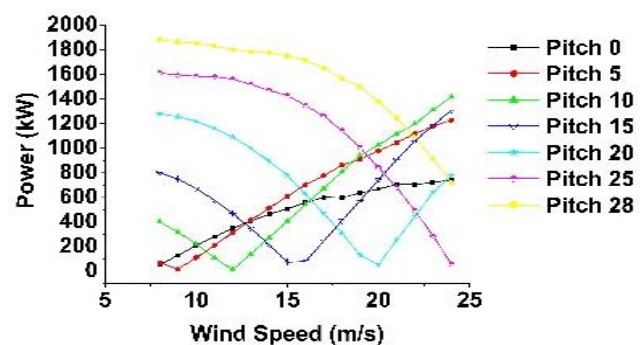

(a)

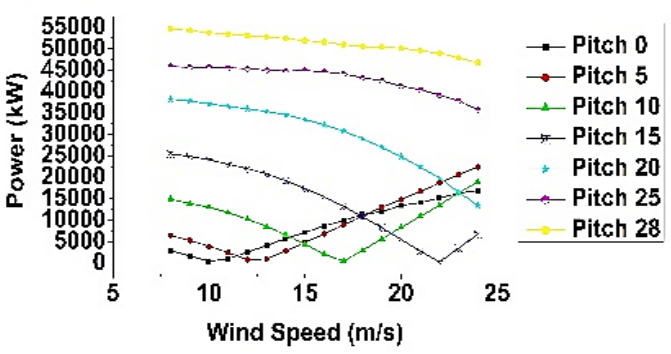

(b)

Figure 5 Power variation curve at different pitch angle for (a) $\omega=1.57 \mathrm{rad} / \mathrm{sec}$, (b) $\omega=2.22 \mathrm{rad} / \mathrm{sec}$

\subsection{Estimation of power coefficient $\left(C_{P}\right)$}

The power coefficient can be calculated using (2) given below.

$$
C_{P}=\frac{T \times \omega}{0.5 \rho A V^{3}}
$$

where $C_{P}=$ Power coefficient

$T=$ torque $(\mathrm{Nm})$

$\omega=$ Angular velocity

$A=$ Area of the rotor

$V=$ wind $\operatorname{speed}(\mathrm{m} / \mathrm{s})$

The power coefficient is an essential non-dimensional parameter in determining the performance of a wind turbine. The power coefficient curve is shown in Figure 6(a) and Figure 6(b) gives an idea about which pitch angle is best to work for and which pitch angle can lead to random behavior. According to the previous studies, the maximum value of power coefficient is set to 0.59 according to Betz's law [43], so keeping this limit in consideration and visualizing Figure 6(a) and Figure 6(b) one can say that values which are more than 0.59 are practically not feasible but in CFD the reason behind of getting such a big value is that losses like mechanical losses, rotor control system losses, pitch control mechanism losses, gear \& shaft losses, etc. are not considered while performing the simulations. From Figure 6(a) it has been observed that for $\omega=1.57 \mathrm{rad} / \mathrm{sec}$ when the blade is given pitch angle $25^{\circ}$ and $28^{\circ}$ best power coefficient obtained at a velocity $10 \mathrm{~m} / \mathrm{s}$, i.e., 0.56 , which is closer to Betz's limit. Blade with pitch angle $20^{\circ}$ also reflects the best power coefficient value as 0.52 when wind speed is considered as $9 \mathrm{~m} / \mathrm{s}$. blade with pitch angle $15^{\circ}$ and velocity $8 \mathrm{~m} / \mathrm{s}$ and blade with pitch angle $28^{\circ}$ and velocity $11 \mathrm{~m} / \mathrm{s}$ also shown the good results of the power coefficient as 0.47 and 0.41 . Figure $6(\mathrm{~b})$, on the other hand, shows some different variations of power coefficient due to different angular velocity, i.e., $2.22 \mathrm{rad} / \mathrm{sec}$. Here in Figure 6(b), the best power coefficient of 0.58 can be seen when the pitch angle $28^{\circ}$ and pitch $10^{\circ}$ is considered for the analysis for the velocity 14 
$\mathrm{m} / \mathrm{s}$ and $9 \mathrm{~m} / \mathrm{s}$. Further when the pitch angle is taken as $15^{\circ}$ and wind speed as $11 \mathrm{~m} / \mathrm{s}$, the power coefficient comes as 0.52 , which is near to Betz's limit and gives a promising output.

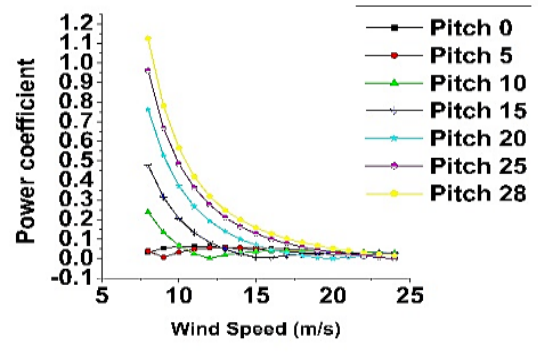

(a)

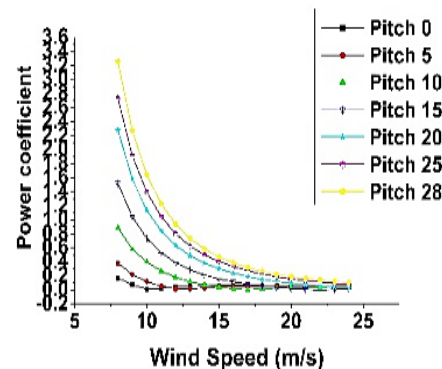

(b)

Figure 6 Power coefficient curve at different pitch angle for (a) $\omega=1.57 \mathrm{rad} / \mathrm{sec}$, (b) $\omega=2.22 \mathrm{rad} / \mathrm{sec}$

\subsection{Verifications}

The numerical examination is checked by comparing it with a normal empirical equation and is illustrated in (3). Variation of the velocity vector is shown in Figure 7(a) and Figure 7(b), and the verification is shown in Table 3. It is to be noted that an additional $1 \mathrm{~m}$ has been considered to account for the distance from the root of the blade to the hub, making the blade length $44.2 \mathrm{~m}$.

$$
\text { Tangential velocity }=r \times \omega
$$

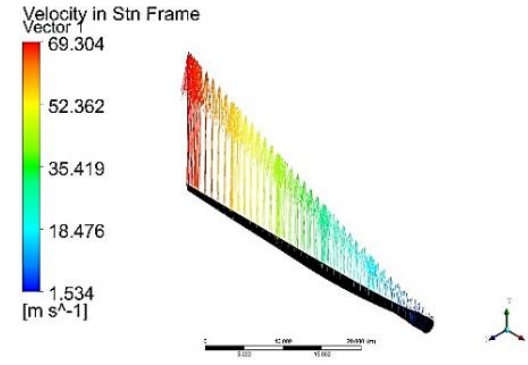

(a)

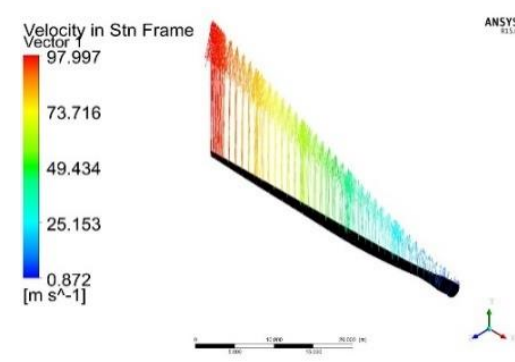

(b)

Figure 7. Tangential velocity of the blade for (a) $\omega=1.57 \mathrm{rad} / \mathrm{sec}$, (b) $2.22 \mathrm{rad} / \mathrm{sec}$

Table 4. Tangential velocity relation

\begin{tabular}{cccccc}
\hline $\begin{array}{c}\text { Pitch angle } \\
(\text { degree })\end{array}$ & $\begin{array}{c}\text { Velocity } \\
(\mathrm{m} / \mathrm{s})\end{array}$ & $\begin{array}{c}\text { Rotational } \\
\text { velocity } \\
(\mathrm{rad} / \mathrm{sec})\end{array}$ & Numerical & Analytical & Error $(\%)$ \\
\hline $5^{\circ}$ & 10 & 1.57 & 69.30 & 69.394 & 0.13 \\
$5^{\circ}$ & 10 & 2.22 & 97.997 & 98.124 & 0.12 \\
\hline
\end{tabular}

\section{CONCLUSIONS}

The rotor has a rotational speed of $1.57 \mathrm{rad} / \mathrm{sec}$ produced less torque and power as compared to $2.22 \mathrm{rads} / \mathrm{sec}$. For both rotational speeds, torque and power show a decreasing trend for pitch angle $25^{\circ}$ and $28^{\circ}$. When rotor rotational speed is taken as $1.57 \mathrm{rad} / \mathrm{sec}$, the optimum pitch angle obtained is $28^{\circ}$ at $10 \mathrm{~m} / \mathrm{s}$, whereas when rotor rotational speed is taken as $2.22 \mathrm{rad} / \mathrm{sec}$ the optimum pitch angle obtained is $10^{\circ}$ and $28^{\circ}$ observed at wind speed $9 \mathrm{~m} / \mathrm{s}$ and $14 \mathrm{~m} / \mathrm{s}$.

In this paper, the Pitch angle plays a vital role in determining the performance parameter of the wind turbines. This paper gives an idea that due to variation in pitch angle, velocity, and angular velocity also induces some impact on aerodynamic characteristics of the wind turbine. Wind turbine performing under different operating conditions reflects variation in torque and power value, which can help a researcher and 
engineer to demarcate the difference between the best pitch angle and worst and design the wind turbine blade accordingly. Apart from this, due to variation in pitch angle, there is uncertainty in pressure distribution of the blade at a specific pitch and absolute velocity, which can lead to blade deformation, and it should be avoided to increase the life span of the wind turbine. This variation in pressure distribution gives an idea about which pitch angle and which velocity should get operated to avoid hazardous like flutter and deformation.

\section{REFERENCES}

[1] Yilmaz, A. S., \& Özer, Z., "Pitch angle control in wind turbines above the rated wind speed by multi-layer perceptron and radial basis function neural networks," Expert Systems with Applications, vol. 36, no. 6, pp. 9767$9775,2009$.

[2] Grieser, B., Sunak, Y., \& Madlener, R., "Economics of small wind turbines in urban settings: An empirical investigation for Germany," Renewable Energy, vol. 78, pp. 334-350, 2015.

[3] Abdelkafi, A., \& Krichen, L., "New strategy of pitch angle control for energy management of a wind farm," Energy, vol. 36, no. 3, pp. 1470-1479, 2011.

[4] J. G. Slootweg, S. W. H. De Haan, H. Polinder and W. L. Kling, "General model for representing variable-speed wind turbines in power system dynamics simulations," IEEE Power Engineering Review, vol. 22, no. 11, pp. 5656, 2002, doi: 10.1109/MPER.2002.4311816.

[5] Fraile, A. Mbistrova, "Wind in power: 2017 european statistics," The European Wind Association, pp. 3-25, 2018.

[6] Subhashini, G., Abdulla, R., \& Mohan, T. R. R., "Wind turbine mounted on a motorcycle for portable charger," International Journal of Power Electronics and Drive Systems (IJPEDS), vol. 9, no. 4, pp. 1814-1822, 2018, doi: 10.11591/ijpeds.v9.i4.pp1814-1822.

[7] Bahaj, A. S., Myers, L., \& James, P. A. B., "Urban energy generation: Influence of micro-wind turbine output on electricity consumption in buildings," Energy and buildings, vol. 39, no. 2, pp. 154-165, 2007.

[8] Rachedi, M. O., Saidi, M. L., \& Arbaoui, F., "MPPT control design for variable speed wind turbine," International Journal of Electrical and Computer Engineering (IJECE), vol. 10, no. 5, pp. 4604-4614, 2020, doi: 10.11591/ijece.v10i5.pp4604-4614.

[9] Liu, Y., Wang, Z., Xiong, L., Wang, J., Jiang, X., Bai, G., \& Liu, S., "DFIG wind turbine sliding mode control with exponential reaching law under variable wind speed," International Journal of Electrical Power \& Energy Systems, vol. 96, pp. 253-260, 2018.

[10] Hocini, Y., Allali, A., \& Boulouiha, H. M., "Power fuzzy adaptive control for wind turbine," International Journal of Electrical and Computer Engineering (IJECE), vol. 10, vol. 5, pp. 5262-5273, 2020, doi: 10.11591/ijece.v10i5.pp5262-5273.

[11] Boureguig, K., Mansouri, A., \& Chouya, A., "Performance enhancements of DFIG wind turbine using fuzzyfeedback linearization controller augmented by high-gain observer," International Journal of Power Electronics and Drive Systems, vol. 11, no. 1, pp. 10-23, 2020, doi: 10.11591/ijpeds.v11.i1.pp10-23.

[12] Ahmedhamdi, R. T., \&amp; Shneen, S. W., "Using position control to improve the efficiency of wind turbine," TELKOMNIKA Telecommunication, Computing, Electronics and Control, vol. 18, no. 6, pp. 3240-3246, 2020, doi: 10.12928/telkomnika.v18i6.16171.

[13] Zare, A., \& Forouzantabar, A., "Adaptive robust control of variable speed wind turbine generator," Bulletin of Electrical Engineering and Informatics, vol. 4, no. 3, pp. 196-203, 2016, doi: 10.11591/eei.v4i3.502.

[14] El-Sharkawy, Mahmoud M., Attia, Mahmoud A., \& Abdelaziz, Almoataz Y., "Enhancement of power system performance with wind farm disturbances," International Journal of Applied Power Engineering (IJAPE), vol. 8, no. 2, 159-172, 2019, doi: 10.11591/ijape.v8.i2.pp159-172.

[15] Fatimazohra, M., Mokhtar, B., \&amp; Benyounes, M., "Sliding mode performance control applied to a DFIG system for a wind energy production," International Journal of Electrical and Computer Engineering (IJECE), vol. 10, no. 6, pp. 6139-6152, 2020, doi:10.11591/ijece.v10i6.pp6139-6152.

[16] El-Sharkawy, M. M., Attia, M. A., \&amp; Abdelaziz, A. Y., "Enhancement of power system performance with wind farm disturbances," International Journal of Applied Power Engineering (IJAPE), vol. 8, no. 2, pp. 159-172, 2019, doi:10.11591/ijape.v8.i2.pp159-172.

[17] Maguiri, O. E., Moussaif, D., Smma, E. A., Abdelmajid, F., Akhiate, A., "Backstepping nonlinear control to maximize energy capture in a variable speed wind turbine," International Journal of Electrical and Computer Engineering (IJECE), vol. 9, no. 6, 4758, 2019, doi:10.11591/ijece.v9i6.pp4758-4766.

[18] Roul, R., \& Kumar, A., "Fluid-structure interaction of wind turbine blade using four different materials: numerical investigation," Symmetry, vol. 12, no. 9, 2020, doi: 10.3390/sym12091467.

[19] Wang, L., Quant, R., \& Kolios, A., "Fluid structure interaction modelling of horizontal-axis wind turbine blades based on CFD and FEA," Journal of Wind Engineering and Industrial Aerodynamics, vol. 158, pp. 11-25, 2016, doi: 10.1016/j.jweia.2016.09.006.

[20] Miller, W Chang, R. Issa, G. Chen, "Review of computer-aided numerical simulation in wind energy," Renew. Sustain. Energy Rev., Vol. 25, pp. 122-134, 2013.

[21] R. Lanzafame, M. Messina, "Horizontal axis wind turbine working at maximum power coefficient continuously," Renew. Energy., vol. 35, pp. 301-306, 2010. 
[22] J.C. Dai, Y.P. Hu, D.S. Liu, X. Long, "Aerodynamic loads calculation and analysis for large scale wind turbine based on combining REM modified theory with dynamic stall model," Renew, Energy, vol. 36, pp. 1095-1104, 2011.

[23] J.R.P. Vaz, J.T. Pinho, A.L Amarante Mesquita, "An extension of BEM method applied lo horizontal-axis wind turbine design," Renew. Energy, vol. 36, pp. 1734-1740, 2011.

[24] E.P.N. Duque, C.P. van Darn, S.C Hughes, "Navier stokes simulations of the NREL Combined experiment phase II rotor," AIAA-99-0037, pp. 143-153, 1999.

[25] G. Xu, LN. Sankar, "Computational study of horizontal axis wind turbines," J. Sol.Energy Eng. Vol. 122, pp. 3539, 2000.

[26] G. Xu, LN. Sankar, "Application of a viscous flow methodology to the NREL phase VI rotor," AIAA-2002-0030, pp. 84-93, 2002.

[27] Thumthae, T. Chitsomboon, "Optimal angle of attack or untwisted blade wind turbine," Renew. Energy, vol. 34, pp. 1279-1284, 2009.

[28] J.-O. Mo, Y.-H. Lee, "CFD Investigation on the aerodynamic characteristics of a small-sized wind turbine of NREL PHASE VI operating with a stall-regulated method,” J. Mech. Sci. Technol., vol. 26, no. 1, pp. 81—92, 2012.

[29] Y. li, K.-J. Paik, T. Xing, P.M. Carrica, "Dynamic overset CFD simulations of wind turbine aerodynamics," Renew. Energy, vol. 37, pp. 285-298, 2012.

[30] B. Krueger, S. Kratz, T. Theopold and S. Soter, "Wear Reduction Control Method in a Blade Pitch System of Wind Turbines," 2019 IEEE 28th International Symposium on Industrial Electronics (ISIE), Vancouver, BC, Canada, 2019, pp. 1107-1112, doi: 10.1109/ISIE.2019.8781106.

[31] Civelek, Z., "Optimization of fuzzy logic (Takagi-Sugeno) blade pitch angle controller in wind turbines by genetic algorithm," Engineering Science and Technology, an International Journal, vol. 23, no. 1, pp. 1-9, 2020.

[32] Iqbal, A., Ying, D., Saleem, A., Hayat, M. A., \& Mehmood, K., "Efficacious pitch angle control of variable-speed wind turbine using fuzzy based predictive controller," Energy Reports, vol. 6, pp. 423-427, 2020.

[33] Yuhendri, M., Muskhir, M., \& Taali, T., "A novel optimum tip speed ratio control of low speed wind turbine generator based on type-2 fuzzy system," Bulletin of Electrical Engineering and Informatics, vol. 8, no. 4, pp. 1189-1197, 2019

[34] Ngo, Q. V., Yi, C., \& Nguyen, T. T., "The maximum power point tracking based-control system for small-scale wind turbine using fuzzy logic," International Journal of Electrical and Computer Engineering (IJECE), vol. 10, no. 4, pp. 3927-3935, 2020, doi: 10.11591/ijece.v10i4.pp3927-3935.

[35] Ik 8Benbouhenni, H., "A comparison study between fuzzy PWM and SVM inverter in NSMC control of stator active and reactive power control of a DFIG based wind turbine systems," International Journal of Applied Power Engineering (IJAPE), vol. 8, no. 1, pp. 78-92, 2019, doi: 10.11591/ijape.v8.i1.pp78-92..

[36] Ahlem, C., Benretem, A., Dobrev, I., \& Barkati, B., "Comparative study of two control strategies proportional integral and fuzzy logic for the control of a doubly fed induction generator dedicated to a wind application," International Journal of Power Electronics and Drive Systems (IJPEDS), vol. 11, no. 1, 263-274, 2020, doi: 10.11591/ijpeds.v11.i1.pp263-274.

[37] Nguyen, T. T., Van-Duc, P., Bach, H. D., Phan, T. M., \& Nguyen, T. T., "Optimal power generation for windhydro-thermal system using meta-heuristic algorithms," International Journal of Electrical and Computer Engineering (IJECE), vol. 10. no. 5, pp. 5123-5130, 2020, doi: 10.11591/ijece.v10i5.pp5123-5130.

[38] Al-Gabalawy, M. A., Hosny, N. S., \& Hussien, S. A., "Cuckoo search algorithm based for tunning both PI and FOPID controllers for the DFIG-Wind energy conversion system," International Journal of Electrical and Computer Engineering (IJECE), vol. 10, no. 6, pp. 6319-6329, 2020, doi: 10.11591/ijece.v10i6.pp6319-6329.

[39] Hassan, S., Abdelmajida, B., Mourad, Z., Aicha, S., \& Abdennaceur, B., "PSO-Backstepping controller of a grid connected DFIG based wind turbine," International Journal of Electrical \& Computer Engineering (IJECE), vol. 10, no. 1, 2020, doi: 10.11591/ijece.v10i1.pp856-867 .

[40] Merzoug, Y., Abdelkrim, B., \& Larbi, B., "Optimal placement of wind turbine in a radial distribution network using PSO method," International Journal of Power Electronics and Drive Systems (IJPEDS), vol. 11, no. 2, pp. 1074-1081, 2020, doi: 10.11591/ijpeds.v11.i2.pp1074-1081.

[41] Fluent, A. N. S. Y. S. Theory guide, 2015.

[42] Mezaal, N. A., Osintsev, K. V., \& Alyukov, S. V., "The computational fluid dynamics performance analysis of horizontal axis wind turbine," International Journal of Power Electronics and Drive Systems (IJPEDS), vol.10, no. 2, 2019, doi: 10.11591/ijpeds.v10.i2.pp1072-1080.

[43] Hansen, M. O., Aerodynamics of wind turbines. Routledge, 2015. 


\section{BIOGRAPHIES OF AUTHORS}
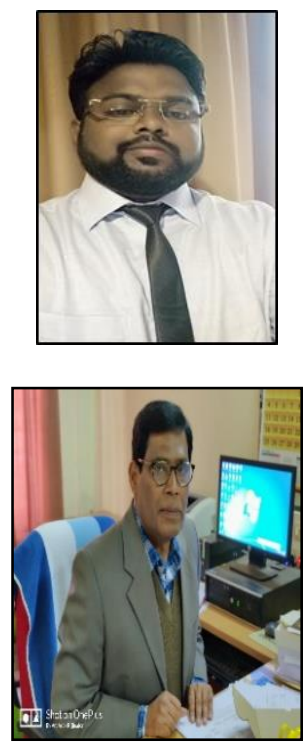

Rajendra Roul is currently pursuing a Ph.D. degree in the department of civil engineering at the National Institute of Technology Rourkela, Odisha, India. His research interests include fluid mechanics, aerodynamics, computational fluid dynamics, fluid-structure interaction, modelling and simulation, structural analysis. Rajendra received his MTech from the National Institute of Technology Rourkela in water resource engineering, having fluid mechanics his core domain in 2015.he received a Bachelor's degree in Mechanical Engineering from GIET University in 2011. He has a good command of both civil and mechanical subjects making his career multidisciplinary. Contact him at E-mail: rajendraroulnit@gmail.com

Awadhesh Kumar is a professor of civil engineering at the National Institute of Technology Rourkela, Odisha, India. His current research interests in the areas of Fluid Mechanics \& Fluidization, Aerodynamics, Water Resources Engineering. He published lots of papers in a well-reputed journal and got awards for outstanding publications. He is a member of MIE(India), MIIChE, and LMISTE.

Contact him at E-mail:akumar@nitrkl.ac.in 